\title{
Article \\ Delays in the Road Construction Projects from Risk Management Perspective
}

\author{
Reza Mohajeri Borje Ghaleh ${ }^{1}$, Towhid Pourrostam ${ }^{1, *}$, Naser Mansour Sharifloo ${ }^{1}$, Javad Majrouhi Sardroud ${ }^{1}$ (D) \\ and Ebrahim Safa ${ }^{2}$
}

1 Ayatollah Hashemi Complex, Department of Civil and Construction Engineering, Central Tehran Branch, Islamic Azad University, Tehran 1469669191, Iran; rez.mohajeri.eng@iauctb.ac.ir (R.M.B.G.); Naser.sharifloo@gmail.com (N.M.S.); j.majrouhi@iauctb.ac.ir (J.M.S.)

2 Shahid Kalantari Complex, Department of Road and Transportation, South Tehran Branch, Islamic Azad University, Tehran 1777613651, Iran; ebr36.safa@gmail.com

* Correspondence: T.Pourrostam@iauctb.ac.ir; Tel.: +9-10-9849-774

check for updates

Citation: Mohajeri Borje Ghaleh, R.; Pourrostam, T.; Mansour Sharifloo, N.; Majrouhi Sardroud, J.; Safa, E. Delays in the Road Construction Projects from Risk Management Perspective. Infrastructures 2021, 6, 135. https://doi.org/10.3390/ infrastructures6090135

Academic Editor:

Giuseppe Loprencipe

Received: 15 July 2021

Accepted: 8 September 2021

Published: 20 September 2021

Publisher's Note: MDPI stays neutral with regard to jurisdictional claims in published maps and institutional affiliations.

Copyright: (c) 2021 by the authors. Licensee MDPI, Basel, Switzerland. This article is an open access article distributed under the terms and conditions of the Creative Commons Attribution (CC BY) license (https:/ / creativecommons.org/licenses/by/ $4.0 /)$.

\begin{abstract}
Delays in the execution stage of road construction projects are one of the significant challenges. The incapability of finishing projects according to schedule has attracted many researchers' attention to this issue. This study has been formed to investigate delays in road construction projects from a risk management perspective. In this study, risks have been identified by structured interviews with experts. Qualitative risk analysis by a survey of experts and quantitative risk analysis by analytical hierarchy process (AHP) technique have been performed. Research results show that financial and credit problems, lands' funding, management problems, technical problems, and natural disasters have the highest risk among the main criteria. Among the subcriteria of the risk, incomplete funding with a weight of 0.188 , gardens and land price with 0.114 are the most critical risk, and ground operations with 0.017 , asphalt problems with 0.009 , and accident insurance with a weight of 0.006 are the least essential risk. In the following, critical criteria analysis has been performed, and solutions to reduce or eliminate these delays in road construction projects are presented.
\end{abstract}

Keywords: risk management; road construction projects; delay; analytical hierarchy process (AHP); execution stage

\section{Introduction}

The delay issue exists in most road construction projects [1]. The Oxford English Dictionary defines delay as "a period of time when someone or something has to wait because of a problem that makes something slow or late" [2]. Increasing the time beyond the planned amount has adverse effects on the project's success in terms of cost, quality, and time [3-7]. Delays can occur in any construction project, but their magnitude varies from project to project [8]. When the project schedule is based on a reasonable time, project uncertainties that affect success will be based on two hypotheses of probability and possibility [9]. To overcome this problem, evaluation of the delay risks is inevitable.

The present study has focused on delay factors in the execution stage of road construction projects. The project's lifecycle has five stages. These steps include the initial stage, the planning stage, the design stage, the execution stage, and the final stage [10]. However, this study has only focused on the execution stage.

The execution stage is the longest and the costliest stage of the project's lifecycle. Moreover, it is the riskiest part of project management [10]. In particular, this is the case if the project management team is not correctly formed or risk management practices are not implemented at all stages of the project lifecycle [11]. Since construction projects are very complex, delay problems occur for a variety of reasons. It is essential to control factors for the successful completion of the project. Although the delay cannot be avoided, recognizing its reasons and the necessary precautions can reduce the effects. 
Rivera et al. [1] have conducted a study to investigate causes of delay in road construction projects across 25 developing countries. From their view, a weak construction manager, incorrect planning/scheduling, influence on people's land alongside the road construction project, poor communication between construction groups, frequent changes in design, shortage of equipment, force majeure, contract modification, delays in execution of progress billing, lack of construction materials, delayed payment to contractors, and poor labor productivity are the most important causes of delay.

Ragunath and Hamed [12] identify the ten principal reasons for delay in construction projects. They are: shortage of building material in the market, material cost increment, delay in material delivery, profitability decrement derived from the financial problem, lack of workforce, the delay in fulfilling the work by the owner, change in material quality, weak presenting of the work and workforce efficiency, banking limitation, and impermissible workforce.

Venkateswaran and Murugasan [13] identify the five principal reasons for delay as land acquisition, many stakeholders, displacement of network, legal requirements, and claims and disputes.

Awari et al. [14] consider weak management, the employer's financial payment to the contractor, inefficient planning and timing of the construction project, the disagreement between the various sides, the shortage of material, and the shortage of workforce as the important reasons for delay.

Pourrostam and Ismail [15] have identified the reasons for delay in the construction projects of Iran by the questionnaire and consider the weak management of the site, contractor financial problems, and the change order by the employer during the construction period the most important reasons for delay. They have evaluated the prioritization of reasons for delay based on the relative importance index.

According to the literature review, it can be expressed that:

- The considered factors in the literature only consider one level of the delay reasons, whereas these factors are related to other factors;

- Although researchers have highlighted many factors of increased time, a large number of them have not suggested possible control measures for these factors.

Therefore, identifying the root causes of delays, qualitative prioritizing, quantitative prioritizing, and providing solutions to reduce their impact on road construction projects from a risk management perspective, are the objectives of this research. Although researchers have highlighted many factors of increased time, a large number of them have not suggested possible control measures for these factors $[16,17]$.

\section{Materials and Methods}

\subsection{Research Methodology}

Risk management is a method to minimize the threat factors and maximize the opportunity factors that have a direct impact on the project objectives, and project management body of knowledge (PMBOK) guide is one of the best risk management models. Because it has public familiarity, ease of access, ease of use, and available support resources, this guide consists of the subprocesses of risk management planning, risk identification, qualitative risk analysis, quantitative risk analysis, risk response planning, risk implementation, and risk monitoring [10]. Risk management planning determines how to deal with threats. In this study, the delays' identification of the execution stage in the road construction projects has been considered by expert opinion and in the form of structured interviews, and the cause and effect (Ishikawa) chart has been used to show qualitative prioritization. The information has been collected by the questionnaire to quantitatively prioritize the delays; the AHP method is used for the data analysis. Then, critical criteria analysis was performed, and solutions were proposed to reduce the effect of these delays in road construction projects. 


\subsection{The Case Study}

The studied project is 18.5 kilometers in the Semnan province range in IRAN (Figure 1). This road is a part of the north-south corridor of IRAN. Characteristics of this road are $10 \mathrm{~km}$ of plains, $2 \mathrm{~km}$ of hills, and $6.5 \mathrm{~km}$ of mountains [18]. This project is facing delays in the execution stage and is suitable for a case study.

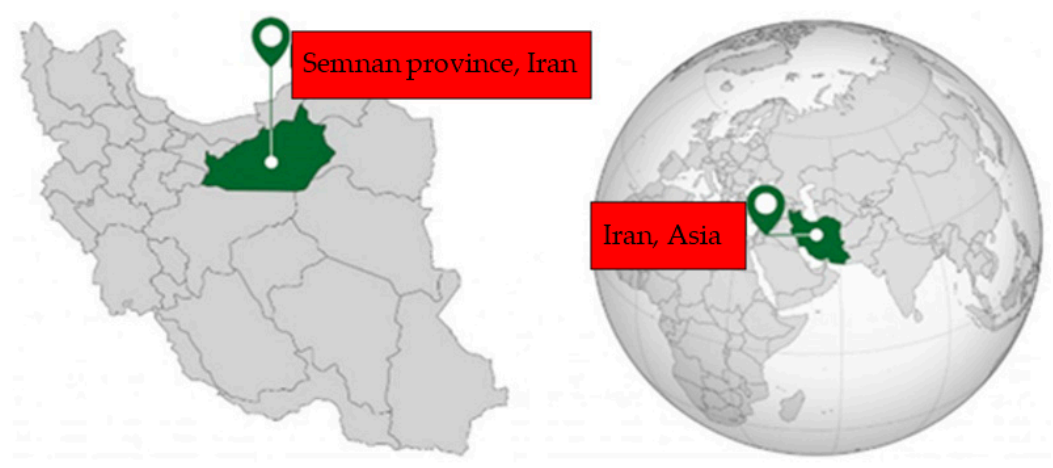

Figure 1. Road project location.

\subsection{Data Collection}

Data Collection has been based on the questionnaire. The validity justifiability for the questionnaire was confirmed by a group of experts in the road construction projects' field, mentioned below to ensure clarity, accuracy, and being meaningful.

- A professor of civil engineering, construction engineering, and management;

- A professor of civil engineering, road, and transportation;

- Two project managers on behalf of the employer;

- A project manager on behalf of the contractor;

- Two project managers on behalf of the consultant.

The reliability justifiability for the questionnaire was confirmed by calculating inconsistency rates. If the inconsistency rate for a pairwise comparison matrix is less than 0.1 , then the pairwise comparison matrix and the corresponding questionnaire are reliable [19-25]; otherwise, pairwise comparisons are made again.

The number of experts that can comment about the importance of the risk scales in the studied road construction project was low. Therefore, all the experts who could comment about the scales' matter have been used. The number of mentioned experts was 20 people, and all their opinions have been used to perform this research. Whereas there was no significant difference between experts for education, experience, and organizational position, the weight of expert opinion has been considered the same.

\subsection{The AHP Method in Theoretical Foundations}

The analytical hierarchical process is one of the most precisely designed systems for multicriteria decision-making [19-22]. Saaty has presented the AHP method for decisionmaking at the risk of unreliability conditions. The selecting reasons for this method for this research are as follows:

1. It provides the possibility of formulating the issue as hierarchical;

2. It can consider the various quantitative and qualitative scales in the issue;

3. It applies the various options in the decision-making and has the possibility of sensitivity analysis on the criteria and subcriteria;

4. It has been created based on the pairwise comparison that facilitates judgment and calculations;

5. It shows decision consistency and inconsistency;

6. It provides group decision-making through group agreement using the geometric mean of individual judgments, which reduces bias in individual decision-making; 
7. It is capable of modeling situations that lack support, such as risk and uncertainty modeling.

Calculate Inconsistency Rates

To calculate the inconsistency rate:

- $\quad$ Create a pairwise comparison matrix (A);

When professional judgments are created, in Table 1, the matrix A (1) arrives in the comparison by geometrical mean (2).

Table 1. Professional judgments.

\begin{tabular}{ccccc}
\hline Decision Makers & $\mathbf{1}$ & $\mathbf{2}$ & $\boldsymbol{\cdots}$ & $\mathbf{N}$ \\
\hline Judgments & $\mathrm{a}_{12}{ }^{1}$ & $\mathrm{a}_{12}{ }^{2}$ & $\cdots$ & $\mathrm{a}_{12}{ }^{\mathrm{N}}$ \\
\hline
\end{tabular}

where 1, 2 and $\mathrm{N}$ is decision makers.

$$
\begin{gathered}
\mathrm{A}=\left[\begin{array}{cccc}
a_{11} & a_{12} & \cdots & a_{1 n} \\
a_{21} & a_{22} & \cdots & a_{2 \mathrm{n}} \\
\vdots & \vdots & & \vdots \\
a_{n 1} & a_{n 2} & \cdots & a_{n n}
\end{array}\right] \\
\mathrm{a}_{12}=\left[\mathrm{a}_{12}{ }^{1} \times \mathrm{a}_{12}{ }^{2} \times \ldots \times \mathrm{a}_{12}{ }^{\mathrm{N}}\right]^{1 / \mathrm{N}}
\end{gathered}
$$

- $\quad$ Create a special vector $(\mathrm{W})$;

First, each column of the matrix normalizes, and then the row mean of the elements calculates until the special vector is obtained.

- Calculate the maximum special value of the matrix ( $\lambda$ max);

$$
\lambda \max =(\mathrm{A} \times \mathrm{W}) / \mathrm{W}
$$

where $\mathrm{A}$ is the pairwise comparison matrix, $\mathrm{W}$ is the weighted vector, and $\lambda$ max is the maximum special value of the matrix [25].

- Calculate the average of the maximum special value of the matrix;

- Calculate the inconsistency index (I.I.);

$$
\text { I.I. }=\frac{\lambda \max -n}{n-1}
$$

where $\lambda$ max is an average of the maximum special value of the matrix, and $\mathrm{n}$ is the size of the reciprocal matrix.

- Calculate the inconsistency rate (I.R.).

$$
\text { I.R. }=\frac{\text { I.I }}{\text { I.I.R. }}
$$

Inconsistency index has been calculated based on inconsistency index at random for each matrix. Inconsistency index at random (I.I.R.) can be obtained from Table 2 [25].

Table 2. Inconsistency index at random.

\begin{tabular}{ccccccccccc}
\hline $\mathbf{N}$ & $\mathbf{1}$ & $\mathbf{2}$ & $\mathbf{3}$ & $\mathbf{4}$ & $\mathbf{5}$ & $\mathbf{6}$ & $\mathbf{7}$ & $\mathbf{8}$ & $\mathbf{9}$ & $\mathbf{1 0}$ \\
\hline I.I.R. & 0 & 0 & 0.58 & 0.9 & 1.12 & 1.24 & 1.32 & 1.41 & 1.45 & 1.49 \\
\hline
\end{tabular}




\section{Data Analysis}

Library resources and the experts' opinion finalized a list of the main criteria and subcriteria of the risks. The qualitative prioritization of delay risks is shown by the cause and effect (Ishikawa) chart (Figure 2). The parameters effective on delay in the road construction projects are divided into two main groups of internal and external factors by the experts' opinion. For internal factors, their origin is of the project itself, and the external factors apply to the project through the environment.

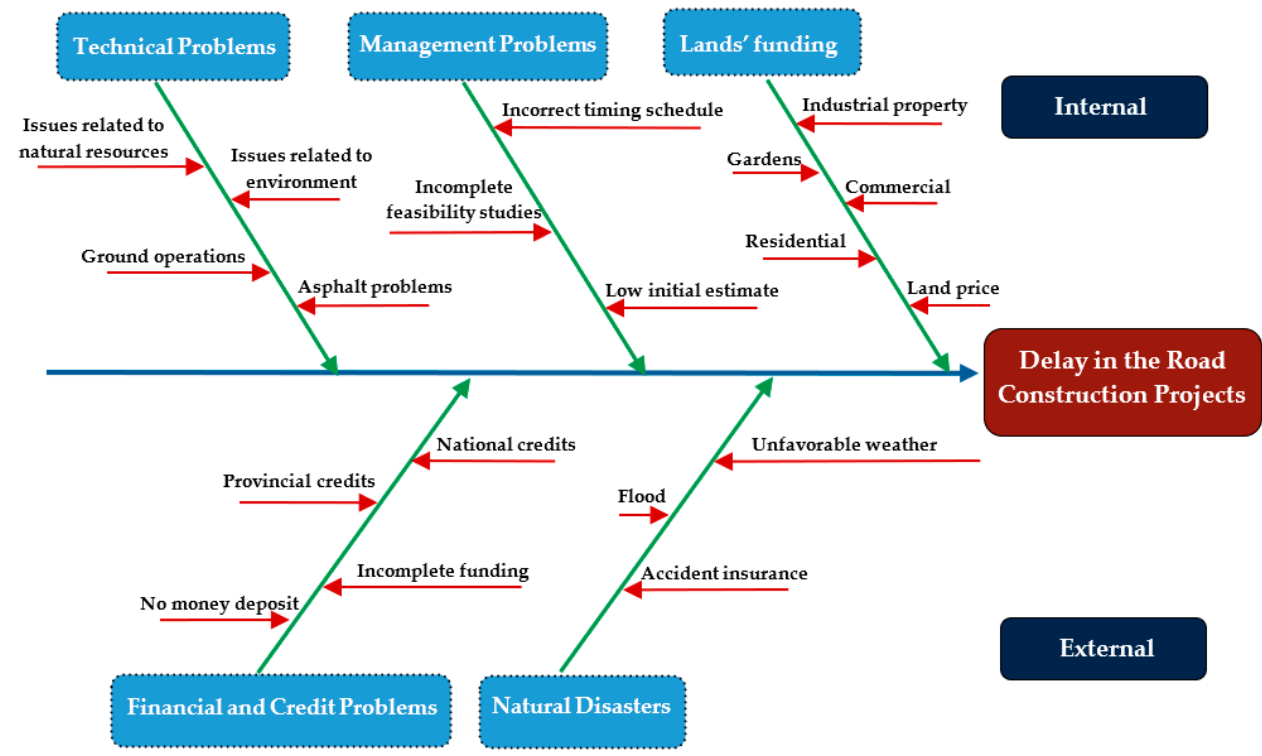

Figure 2. The qualitative prioritization of delay risks by the experts' opinion.

\subsection{The Lands' Funding}

To build a road, the lands' funding must be complete. According to the ownership and various uses of the road environment lands, the lands' funding will increase the construction time. Therefore, the delay due to lands' funding has been categorized into subsections such as land price, gardens, residential, commercial, and industrial property, such that each of them has their problems.

\subsection{Management Problems}

This part of delay was derived from the project studies phase and includes an incorrect timing schedule, a low initial estimate, and incomplete feasibility studies. If presenting the management analyses of the plan is performed correctly, this problem will arise less in the execution stage.

\subsection{Technical Problems}

This type of problem is related to the used material for the execution stage of the road construction projects that includes asphalt problems, problems related to the ground operations, issues related to environment organization, and issues related to natural resources organization.

\subsection{Financial and Credit Problems}

The financial problems are more related to allocation and credits. The credits section can be divided into the national credits and provincial credits, and the allocation section problems include incomplete funding and no money deposit. The financial issues weaken the contractor's economic power, and the execution time will increase. 


\subsection{Natural Disasters}

Natural disasters are a part of the out-of-project factors that apply to the project from the environment. These factors include unfavorable weather conditions, flood, and accident insurance.

By collecting expert opinions in the form of linguistic statements, a pairwise matrix was obtained to quantitatively prioritize the risks. Then, the pairwise comparisons' matrix about the main criteria and subcriteria has been accumulated. Six pairwise comparison matrixes have been made to collect the experts' opinions in performing the pairwise comparison between the hierarchical elements. The first pairwise comparison has been made between the main criteria effective on the hierarchical first row. The various risks are compared with each other to specify their effect on the execution stage of the road projects. In the following, the impact of subcriteria on the delay and the level of their impact on the main criteria have been compared. Tables $3-8$ show the pairwise comparisons matrix for the main criteria and subcriteria.

For ensuring opinions' consistency in all the pairwise comparison matrixes, the inconsistency rate was calculated. The inconsistency rate for the main criteria is equal to

$$
\lambda \max =5.033 \rightarrow\left\{\begin{array}{c}
\text { I.I. }=0.0083 \\
\text { I.R. }=0.0074<0.1
\end{array}\right.
$$

The financial and credit risk identified as the most critical risk and lands' funding, management problems, technical problems, and natural disasters are in the next stage.

$$
\lambda \max =4.823 \rightarrow\left\{\begin{array}{c}
\text { I.I. }=-0.044 \\
\text { I.R. }=-0.049<0.1
\end{array}\right.
$$

In the lands' funding group, the land price and gardens have the most important value, and the residential, commercial, and industrial areas are in the subsequent steps.

$$
\lambda \max =3 \rightarrow\left\{\begin{array}{c}
\text { I.I. }=0 \\
\text { I.R. }=0<0.1
\end{array}\right.
$$

Incomplete feasibility studies, incorrect timing schedule, and low initial estimate have risks, respectively, in the management problems group.

$$
\lambda \max =4.0076 \rightarrow\left\{\begin{array}{l}
\text { I.I. }=0.0025 \\
\text { I.R. }=0.0028<0.1
\end{array}\right.
$$

Issues related to the natural resources, issues related to environment, the ground operations, and the asphalt problems have the most risk in the technical problems group.

$$
\lambda \max =4.0076 \rightarrow\left\{\begin{array}{l}
\text { I.I. }=0.0025 \\
\text { I.R. }=0.0069<0.1
\end{array}\right.
$$

In the financial and credit group, the incomplete funding, the provincial credits, no money deposit, and the national credits have the most amount of risk.

$$
\lambda \max =3.0246 \rightarrow\left\{\begin{array}{c}
\text { I.I. }=0.0123 \\
\text { I.R. }=0.021<0.1
\end{array}\right.
$$

In the natural disasters group, the flood, the unfavorable weather conditions, and the accident insurance have importance, respectively. 
Table 3. The pairwise comparisons matrix for main criteria.

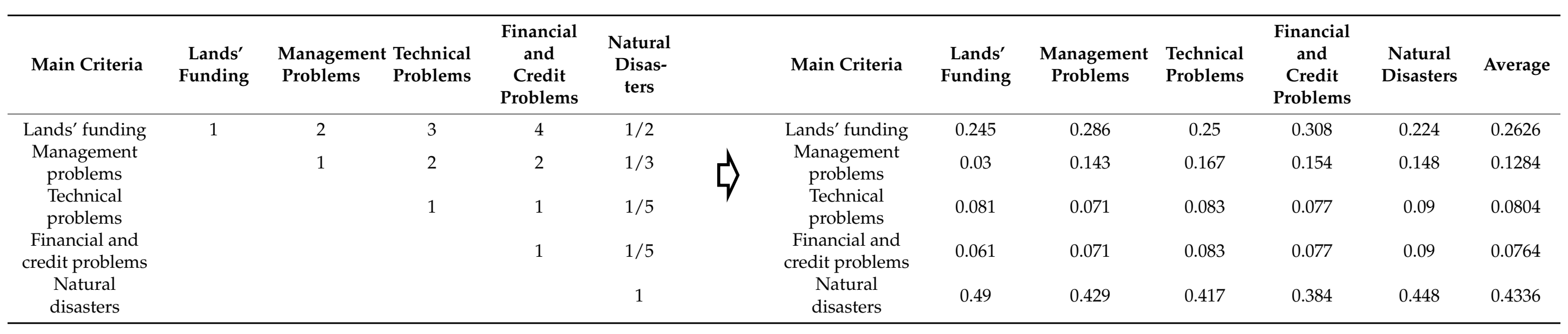

Table 4. The pairwise comparisons matrix for lands' funding.

\begin{tabular}{|c|c|c|c|c|c|c|c|c|c|c|c|c|}
\hline Lands' Funding & $\begin{array}{l}\text { Land } \\
\text { Price }\end{array}$ & Residential & Commercial & Gardens & $\begin{array}{l}\text { Industrial } \\
\text { Property }\end{array}$ & Lands' Funding & $\begin{array}{l}\text { Land } \\
\text { Price }\end{array}$ & Residential & Commercial & Gardens & $\begin{array}{l}\text { Industrial } \\
\text { Property }\end{array}$ & Average \\
\hline Land price & 1 & 2 & 3 & 1 & 4 & Land price & 0.325 & 0.308 & 0.353 & 0.325 & 0.308 & 0.3238 \\
\hline Residential & & 1 & 1 & $1 / 2$ & 2 & Residential & 0.162 & 0.154 & 0.118 & 0.162 & 0.154 & 0.15 \\
\hline Gardens & & & & 1 & 4 & Gardens & 0.325 & 0.308 & 0.353 & 0.325 & 0.308 & 0.3238 \\
\hline $\begin{array}{l}\text { Industrial } \\
\text { property }\end{array}$ & & & & & 1 & $\begin{array}{l}\text { Industrial } \\
\text { property }\end{array}$ & 0.081 & 0.077 & 0.059 & 0.081 & 0.077 & 0.075 \\
\hline
\end{tabular}


Table 5. The pairwise comparisons matrix for management problems.

\begin{tabular}{|c|c|c|c|c|c|c|c|c|c|c|}
\hline $\begin{array}{l}\text { Technical } \\
\text { Problems }\end{array}$ & $\begin{array}{l}\text { Asphalt } \\
\text { Problems }\end{array}$ & $\begin{array}{c}\text { Ground } \\
\text { Opera- } \\
\text { tions }\end{array}$ & $\begin{array}{c}\text { Issues } \\
\text { Related to } \\
\text { Natural } \\
\text { Resources }\end{array}$ & $\begin{array}{l}\text { Issues } \\
\text { Related } \\
\text { to Envi- } \\
\text { ronment }\end{array}$ & $\begin{array}{l}\text { Technical } \\
\text { Problems }\end{array}$ & $\begin{array}{c}\text { Asphalt } \\
\text { Problems }\end{array}$ & $\begin{array}{c}\text { Ground } \\
\text { Operations }\end{array}$ & $\begin{array}{c}\text { Issues } \\
\text { Related to } \\
\text { Natural } \\
\text { Resources }\end{array}$ & $\begin{array}{l}\text { Issues } \\
\text { Related to } \\
\text { Environ- } \\
\text { ment }\end{array}$ & Average \\
\hline $\begin{array}{l}\text { Ground } \\
\text { operations }\end{array}$ & & 1 & $1 / 2$ & $1 / 2$ & $\begin{array}{l}\text { Ground } \\
\text { operations }\end{array}$ & 0.2 & 0.1818 & 0.1766 & 0.1818 & 0.1851 \\
\hline $\begin{array}{l}\text { Issues related to } \\
\text { natural resources }\end{array}$ & & & 1 & 1 & $\begin{array}{l}\text { Issues related to } \\
\text { natural resources }\end{array}$ & 0.3 & 0.3636 & 0.3533 & 0.3636 & 0.3451 \\
\hline
\end{tabular}

Table 6. The pairwise comparisons matrix for technical problems.

\begin{tabular}{|c|c|c|c|c|c|c|c|c|c|c|}
\hline $\begin{array}{l}\text { Technical } \\
\text { Problems }\end{array}$ & $\begin{array}{l}\text { Asphalt } \\
\text { Problems }\end{array}$ & $\begin{array}{c}\text { Ground } \\
\text { Opera- } \\
\text { tions }\end{array}$ & $\begin{array}{c}\text { Issues } \\
\text { Related to } \\
\text { Natural } \\
\text { Resources }\end{array}$ & $\begin{array}{l}\text { Issues } \\
\text { Related } \\
\text { to Envi- } \\
\text { ronment }\end{array}$ & $\begin{array}{l}\text { Technical } \\
\text { Problems }\end{array}$ & $\begin{array}{c}\text { Asphalt } \\
\text { Problems }\end{array}$ & $\begin{array}{c}\text { Ground } \\
\text { Operations }\end{array}$ & $\begin{array}{c}\text { Issues } \\
\text { Related to } \\
\text { Natural } \\
\text { Resources }\end{array}$ & $\begin{array}{c}\text { Issues } \\
\text { Related to } \\
\text { Environ- } \\
\text { ment }\end{array}$ & Average \\
\hline $\begin{array}{l}\text { Ground } \\
\text { operations }\end{array}$ & & 1 & $1 / 2$ & $1 / 2$ & $\begin{array}{l}\text { Ground } \\
\text { operations }\end{array}$ & 0.2 & 0.1818 & 0.1766 & 0.1818 & 0.1851 \\
\hline $\begin{array}{l}\text { Issues related to } \\
\text { natural resources }\end{array}$ & & & 1 & 1 & $\begin{array}{l}\text { Issues related to } \\
\text { natural resources }\end{array}$ & 0.3 & 0.3636 & 0.3533 & 0.3636 & 0.3451 \\
\hline
\end{tabular}


Table 7. The pairwise comparisons matrix for financial and credit problems.

\begin{tabular}{|c|c|c|c|c|c|c|c|c|c|c|}
\hline $\begin{array}{l}\text { Financial and } \\
\text { Credit Problems }\end{array}$ & $\begin{array}{c}\text { National } \\
\text { Credits }\end{array}$ & $\begin{array}{l}\text { Provincial } \\
\text { Credits }\end{array}$ & $\begin{array}{l}\text { Incomplete } \\
\text { Funding }\end{array}$ & $\begin{array}{c}\text { No } \\
\text { Money } \\
\text { Deposit }\end{array}$ & $\begin{array}{l}\text { Financial and } \\
\text { Credit Problems }\end{array}$ & $\begin{array}{l}\text { National } \\
\text { Credits }\end{array}$ & $\begin{array}{l}\text { Provincial } \\
\text { Credits }\end{array}$ & $\begin{array}{l}\text { Incomplete } \\
\text { Funding }\end{array}$ & $\begin{array}{l}\text { No Money } \\
\text { Deposit }\end{array}$ & Average \\
\hline National credits & 1 & $1 / 2$ & $1 / 5$ & $1 / 2$ & National credits & 0.1 & 0.091 & 0.112 & 0.077 & 0.095 \\
\hline $\begin{array}{l}\text { Incomplete } \\
\text { funding }\end{array}$ & & & 1 & 4 & $\begin{array}{l}\text { Incomplete } \\
\text { funding }\end{array}$ & 0.5 & 0.545 & 0.562 & 0.615 & 0.5555 \\
\hline No money deposit & & & & 1 & $\begin{array}{l}\text { No money } \\
\text { deposit }\end{array}$ & 0.2 & 0.182 & 0.14 & 0.154 & 0.169 \\
\hline
\end{tabular}

Table 8. The pairwise comparisons matrix for natural disasters.

\begin{tabular}{|c|c|c|c|c|c|c|c|c|}
\hline Natural Disasters & $\begin{array}{c}\text { Unfavorable } \\
\text { Weather } \\
\text { Conditions }\end{array}$ & Flood & $\begin{array}{l}\text { Accident } \\
\text { Insurance }\end{array}$ & Natural Disasters & $\begin{array}{c}\text { Unfavorable } \\
\text { Weather } \\
\text { Conditions }\end{array}$ & Flood & $\begin{array}{l}\text { Accident } \\
\text { Insurance }\end{array}$ & Average \\
\hline $\begin{array}{c}\text { Unfavorable } \\
\text { weather conditions }\end{array}$ & 1 & $1 / 2$ & 4 & $\begin{array}{l}\text { Unfavorable weather } \\
\text { conditions }\end{array}$ & 0.308 & 0.294 & 0.4 & 0.334 \\
\hline Flood & & 1 & 5 & Flood & 0.615 & 0.588 & 0.5 & 0.565 \\
\hline Accident insurance & & & 1 & Accident insurance & 0.077 & 0.118 & 0.1 & 0.098 \\
\hline
\end{tabular}


The inconsistency rate of the main criteria and subcriteria was less than 0.1 . Therefore, the questionnaires are reliable and Saaty opinion is confirmed [21]. Quantitative assessment of risks indicates that financial and credit problems with a weight of 0.434 are the most important, and in the next ranks are lands' funding with the weight of 0.263 , management problems with the weight of 0.146 , technical problems with a weight of 0.080 , and natural disasters with an overall weight of 0.076 .

The normalized weight has been calculated for each of the existing elements in the hierarchy by the Expert Choice software (Figure 3). In general, the prioritizing shows that the incomplete funding with 0.188 weight is specified as the most critical risk. Land price and gardens with 0.114 weight are in the second rank, and the incomplete feasibility studies and incorrect timing schedule with 0.064 are in the third rank. In the following, provincial credits with 0.061 , no money deposit with 0.057 , residential areas with 0.052 , commercial areas with 0.045 , issues related to the natural resources with 0.035 , issues related to environment with 0.033 , flood with 0.033 , low initial estimate with 0.032 , national credits with 0.032 , industrial property with 0.026 , unfavorable weather conditions with 0.019 , ground operations with 0.017 , asphalt problems with 0.009 , and accident insurance with 0.006 have the subsequent ranks.

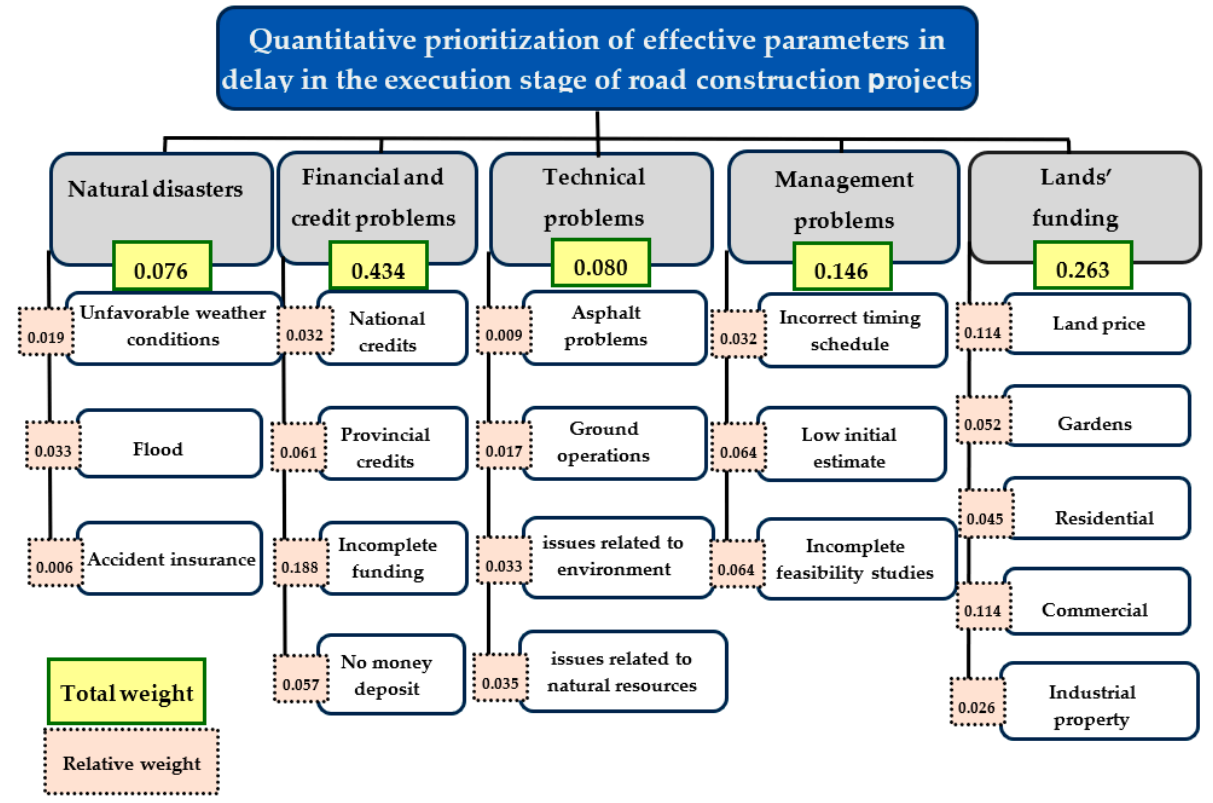

Figure 3. The relative and total weight of the criteria and subcriteria.

\section{Discussion}

\subsection{Critical Criteria Analysis}

\subsubsection{Lack of Sufficient Funding}

One of the most important factors influencing the delays of road construction projects is the lack of funding for the project. Lack of planning to provide funding before the tender and the lack of allocation of the required annual budget regularly have a great impact on increasing the time of projects.

\subsubsection{Acquisition of Lands around the Road}

Most road construction projects require the widening of the way and the acquisition of lands around the road. According to the real estate issue, land should be bought from individuals. Reaching an agreement on land prices and carrying out administrative follow-ups such as obtaining ownership of individuals, preparing a roadmap will increase project time. 


\subsubsection{Lack of Experienced and Knowledgeable People}

Lack of experienced and specialized people on the management staff causes problems in the initial studies phase. In the design phase, a low estimate of costs and activities is provided, and an incorrect schedule is presented in the work process. These mistakes will eventually increase the project time.

\subsubsection{Lack of Machinery}

The financial capacity of the contractor as an executor has a significant impact on the progress of the project. Contractors who have fewer financial capacities and do not provide sufficient machinery to the project increase the project time by prolonging the execution process in the ground operations and asphalt operations.

\subsubsection{Issues Related to the Environment and Natural Resources}

When the road passes through protected areas, issues related to the environment and doing administrative follow-up will increase project time. Withdrawal of materials for the implementation of pavement layers from mines and riverbeds requires agreement with natural resources, which increases the time.

\subsubsection{Natural Disasters}

The climatic condition of the region's road construction, especially rainfall and air temperature, is of particular importance. This is because they affect the road construction process and maybe delay or stop road construction operations. Rain saturates the soil and disrupts road construction operations. Implementation of concrete bridges is difficult in cold weather, especially in mountainous areas. Asphalt is impossible in cold seasons. Heavy rains cause floods, causing damage and the need for repairs for routes under construction.

\subsection{Solutions}

According to the results obtained from this study, solutions and suggestions to reduce the impact of these criteria are present:

1. Perform careful and realistic planning before implementation;

2. Ensure the existence of funding required for the project;

3. Choose a strong management team;

4. Select a qualified contractor to implement the project;

5. Introduce natural disasters in the implementation of activities.

\section{Conclusions}

Due to the importance of delays, it is necessary to investigate and analyze their factors. Although the delay cannot be avoided, it can be reduced with the required precautions. In this study, we investigate delays from a risk management perspective that offers a robust framework for delay control. This framework prioritizes risks, analyzes critical criteria, provides solutions to reduce delays, and helps improve the construction process.

In this research, a framework has been presented to identify and prioritize the risks of delay for the road construction projects with the AHP method. The framework discusses delays from a system management perspective and the group AHP method serves as a tool for studying and decreasing the inconsistencies rate determined by the experts. The Ishikawa chart has provided a powerful tool for identifying and prioritizing qualitative risks, and the AHP method has provided a powerful method for quantitative risks. The offered framework for a road construction project in the execution stage shows how the framework can help the decision-makers by implementing all risk management processes.

Research results show that financial and credit problems with a weight of 0.434 , lands funding with a weight of 0.263 , management problems with a weight of 0.146 , technical problems with a weight of 0.080 , and natural disasters with an overall weight of 0.076 are the most important, respectively. We determine the relative weight of incomplete funding 
with a weight of 0.188 in the first place, gardens and land price with 0.114 in the second place, and incorrect timing schedule and incomplete feasibility studies with 0.064 in the third place; provincial credits with 0.061 , no money deposit with 0.057 , residential areas with 0.052 , commercial areas with 0.045 , issues related to natural resources with 0.035 , and issues related to environment and flood with 0.033 , respectively. Low initial estimate and national credits with 0.032 , industrial property with 0.026 , unfavorable weather conditions with 0.091, ground operations with 0.017, asphalt problems with 0.009, and accident insurance with 0.006 relative weight with relative ratings next are the quantitative risk assessments.

We investigated delays from a risk management perspective and showed that it is a powerful method for prioritizing delays because it provides a plan to respond to the critical criteria, and this plan does not exist in other methods. However, in the prioritization, the risks that are of high importance may be low cost in the project. Whereas the risks that are of low importance may be very costly to the project. Therefore, further research is needed to develop a method to quantify the cost-effectiveness of risks.

Author Contributions: Conceptualization, R.M.B.G. and T.P.; methodology, R.M.B.G. and J.M.S.; software, R.M.B.G.; validation, R.M.B.G., T.P., N.M.S. and E.S.; formal analysis, R.M.B.G. and J.M.S.; investigation, R.M.B.G. and T.P.; resources, R.M.B.G.; data curation, R.M.B.G. and E.S.; writingoriginal draft preparation, R.M.B.G.; writing—review and editing, R.M.B.G. and J.M.S.; supervision, T.P. and N.M.S. All authors have read and agreed to the published version of the manuscript.

Funding: This research received no external funding.

Conflicts of Interest: The authors declare no conflict of interest.

\section{References}

1. Rivera, L.; Baguec, H.J.; Yeom, C. A Study on Causes of Delay in Road Construction Projects across 25 Developing Countries. Infrastrutures 2020, 5, 84. [CrossRef]

2. Oxford University Press (OUP). Oxford English Dictionary (OED); Oxford University Press: Oxford, UK, 2021. Available online: https:/ /www.oed.com (accessed on 10 March 2021).

3. Assef, S.A.; Al-Hejji, S. Cusess of delay in large construction projects. Int. J. Proj. Manag. 2006, 23, 349-357. [CrossRef]

4. Koushki, P.A.; Al-Rashid, K.; Kartam, N. Delay and cost increases in the construction of private residential project in Kuwait. Constr. Manag. Econ. 2005, 23, 285-294. [CrossRef]

5. Heydariyeh, S.A.; Kheirandish, A. Investigating the causes of delay in construction projects and determining their impact on cost, time and quality criteria. In Proceedings of the World Conference on Management, Accounting Economics and Humanities at the Beginning of the Third Millennium, Shiraz, Iran, 19 May 2016. Available online: https:/ / www.symposia.ir/MEAHB01 (accessed on 29 January 2021).

6. Kalugin, Y.B. Reasons of delays in construction projects. Mag. Civ. Eng. 2017, 6, 61-69.

7. Mejia, G.; Sánchez, O.; Castañeda, K.; Pellicer, E. Delay causes in road infrastructure projects in developing countries. Rev Constr. 2020, 19, 220-234. [CrossRef]

8. Amandin, M.M.; Kule, J.W. Project delays on cost overrun risks: A study of gasabo district construction projects Kigali. ABC J. Adv. Res. 2016, 5, 21-34. [CrossRef]

9. Naderpour, A.; Majrouhi Sardroud, J.; Mofid, M.; Xenidis, Y.; Pourrostam, T. Uncertainty management in time estimation of construction projects: A systematic literature review and new model development. Sci. Iran. A 2019, 26, 752-778. [CrossRef]

10. Project Management Institute (PMI). A Guide to the Project Management Body of Knowledge (PMBOK®Guide), 7th ed.; Project Management Institute: Newtown Square, PA, USA, 2021. Available online: https://www.pmi.org/pmbok-guide-standards/ foundational/pmbok (accessed on 15 May 2021).

11. Khodeir, L.M.; Nabawy, M. Identifying key risks in infrastructure projects-Case study of Cairo Festival City project in Egypt. Ain Shams Eng. J. 2019, 10, 613-621. [CrossRef]

12. Ragunath, S.K.; Hameed, M.S. Ranking of delay factors in multi story building projects. Int. Res. J. Eng. Technol. 2018, 5, 1582-1586.

13. Venkateswaran, C.B.; Murugasan, R. Time delay and cost overrun of road over bridge (ROB) construction projects in India. J. Constr. Dev. Ctries. 2017, 22, 79-96. [CrossRef]

14. Awari, S.G.; Narwade, R.; Jamgade, M. Analysis for cause identification for delay in building construction industry. Int. J. Modern Trends Eng. Res. 2016, 3, 28-32.

15. Purrostam, T.; Ismail, A. Study of Methods for Minimizing Construction Delays: Evidences from Developing Country. Adv. Matrials Res. 2011, 201-203, 2932-2943. [CrossRef] 
16. Roslan, N.; Zainun, N.Y.; Memon, A.H. Measures for controlling time and cost overrun factors during execution stage. Int. J. Constr. Technol. Manag. 2015, 1, 8-11.

17. Bovteev, S.V.; Kanyukova, S.V. Development of methodology for time management of construction projects. Mag. Civ. Eng. 2016, 2, 102-112. [CrossRef]

18. Dehuk Parsian Consulting Engineers Company. Consultant Reports; Dehuk Parsian Consulting Engineers Company: Tehran, Iran, 2016.

19. Saaty, T.L. Decision-making with the AHP: Why is the principal eigenvector necessary. Eur. J. Oper. Res. 2002, 145, 85-91. [CrossRef]

20. Saaty, T.L. Fundamentals of Decision Making and Priority Theory, 2nd ed.; RWS Publications: Pittsburgh, PA, USA, 2000.

21. Saaty, T.L. How to make a decision-The analytic hierarchy process. Eur. J. Oper. Res. 1990, 48, 9-26. [CrossRef]

22. Saaty, T.L. The Analytical Hierarchy Process; McGraw Hill: New York, NY, USA, 1980.

23. Ishizaka, A.; Labib, A. Analytic hierarchy process and expert choice: Benefits and limitations. OR Insight 2009, 22, 201-220. [CrossRef]

24. Ghodsipoor, H. Analytical Hierarchy Process (AHP), 4th ed.; Amir Kabir University Press: Tehran, Iran, 2019.

25. Asgharpour, M.J. Multiple Criteria Decision Making, 13th ed.; Tehran University Press: Tehran, Iran, 2020. 